\title{
Enlightenment to Our Country Based On Europe and the United States National Non-Material Cultural Heritage Legal Protection Experience
}

\author{
Shu-Juan Liu \\ Political Department, Hunan University of international Economics, Changsha, P.R. China
}

561524213@qq.com

Keywords: The European and American countries, Intangible cultural heritage, Development, Protect.

\begin{abstract}
Foreign countries have a mature experience in the aspect of the development and protection of the intangible cultural heritage, The accurate evaluation as well as the value of the intangible cultural heritage; Great importance to protecting non-material cultural heritage of the perfection of laws and regulations; To protect the non-material cultural heritage of work and the corresponding development market work organic together; From the academic support and the development of the intangible cultural heritage protection related work, emphasis on public education propaganda etc. Analyzing the practice and experience can get a lot of important enlightenment and reference.

Those who depend on people of faith, life, habits, emotions and produced culture are the intangible cultural heritage. Under the influence of collective social got fully cultivate the consistency involved in non-material cultural heritage, national identity has been enhanced, national spirit has been strengthened, and also to shape the national character. As for the intangible cultural heritage, it is not just a kind of social ideology, it is a kind of cultural heritage with a long history. In many countries around the world to protect, develop their intangible cultural heritage are doing very well, also accumulated a lot of advanced experience, the experience both exist in common, and of particular features. Through research and analysis the experience, we can get a lot of important enlightenment and reference.
\end{abstract}

\section{Experience on the development and protection of the intangible cultural heritage}

\section{The government attaches great importance to the protection of intangible cultural heritage}

Many countries such as Britain, France is given its own intangible cultural heritage with enough attention, and financially support the relevant development and protection In France, thvee protection of historical and cultural heritage is one of the important functions of the gornment. France in the last century 60s organized a massive census of cultural heritage, in view of the activities were found in those intangible cultural heritage made detailed instructions and registration. In addition, the government also set up a batch of specialized area protection of traditional houses, the government provides the architecture of the protected area, maintenance. For the protection of intangible cultural heritage of the work, the British government is also very seriously, and that is why the can inherit, save a lot of old folk habits. In particular, the practice of Scotland. As is known to all, bagpipes and Scotland skirt is two main symbol of the Scottish national. When go out to visit, Prince Charles, once through the kilt to attend; the royal celebrations in large, also has repeatedly organization royal Scottish bagpipe band playing. Get effective protection for the national dance,

the British set up the special royal Scottish country dance association, the queen of England also gives its long-term funding. Bagpipes and country dance is under the favorable social atmosphere to the youth of the acclaimed [1].

\section{Great importance to protecting non-material cultural heritage of the continuous improvement of the relevant laws and regulations}

Caused by many developed countries in the face of modern crisis of intangible cultural heritage, has made a lot of laws and regulations, set up a relatively perfect protection mechanism of intangible cultural heritage with the corresponding incentive policy, from the mechanism and 
system in order to give the protection of intangible cultural heritage work to support. In France, for example, to protect the historical block with the traditional local-style dwelling houses, it established the historical block protection act, the urban planning act and its regulations, shall not be arbitrarily to buy and sell, the transformation of those identified as non-material cultural heritage of architecture. In France, only received permission from ministry of culture can also be bought and sold in cultural relics, including folk cultural relics) [2]. The journal of the American folklore protection act was passed in 1976, its thought in the aspect of the founding of the power, folk has a very important role, so should give rather than to take seriously. The law requires, in the library of congress set "folklore protection center", with the aid of modern means to collect, protect, and rescue ethnic folklore.

\section{Combine the protection of intangible cultural heritage with the development of market-oriented work effectively}

Many countries are intangible cultural heritage and economic development together, put it as the important tourism resources development, build a batch of unique local characteristics of tourism landscape, culture, and project, to the local supervising huge economic benefits. In the UK, and will work to protect intangible cultural heritage and tourism, promote each other, benign circulation. In Britain, the museum is a common kind of tourist attractions, is also focusing on important place of folk crafts, have great attraction for visitors. For example, Albert and Victoria museum has shown the traditional textile technique and embroidery. For Edinburgh, it is one of the most famous Scottish amorous feelings. Held each year in the international art festival, its are such the performance of the military band, and the most popular is the Edinburgh military tattoo show, and it is the most distinct symbol of the Scottish kilt and bagpipe [3]. Especially in recent years, under the influence of folk custom tourism, of Britain and pour a combination of holiday village folk custom tourism, sightseeing and leisure projects, vigorously sought after by the passengers.

\section{Extensive participation in civil organizations and the masses}

Foreign focus on the job to protect intangible cultural heritage, especially in capital raising, training, education and promotion activities organization these organizations have great role. In America, for example, the civil organizations began to work in the protection of intangible cultural heritage, many laws and regulations about protecting cultural heritage. At the same time, non-governmental organizations also gives protection to compulsory counseling and money to help, plus enterprise and individual charitable donations, the problem of insufficient government investment has been effectively solved. In Italy, when making decisions related to and protection of cultural heritage, folk organization can directly involved, it is a professional consulting party for the government. Italy's legal requirements only get the permission of folk organization, to repair or remove those who have already been incorporated in the scope of protection of historic blocks and residential [4]. In addition, these folk organization also regularly about the construction license issuing organization meetings, and submit to the government's opinions.

\section{To do a good job of education propaganda from the children}

In order to enhance the consciousness of people in protecting culture, many developed countries attaches great importance to giving play to the role of propaganda and education, let the masses support and advocacy to protect intangible cultural heritage. Many countries are grabbed by a child, make children age is under the influence of intangible cultural heritage, thus lay the basis of inheriting intangible cultural heritage. Opening campuses abroad, ngos will heritage garden, curriculum for young people the protection of cultural heritage, to hire experts to lectures for young people, and also by means of folk heritage showroom to organize the vivid teaching activities at the scene. Again, for example, in Italy, since 1997, each year in May, the government will organize "cultural heritage week" activities. To let people to the knowledge of the intangible cultural heritage have a full understanding of, the government's heritage will organize folk song and dance 
performances. In addition, the Italian government has also set up in the university and the protection of intangible cultural heritage related courses, professional.

\section{Set up specialized agencies to carry out the relevant protection}

If you want to make more efficient protection of non-material cultural heritage, we must rely on specialized agencies and departments, in order to increase organization security work. According to the part of the developed countries, they have long been aware that the importance of specialized agencies. Italy, put the protection of the intangible cultural heritage in the national interest level, to protect the cultural heritage as an important government responsibility, on the system adopted the vertical management way of the central government. Department of national heritage will be sent across to the representative, the representative to accept vertical leadership of the central government, the wage undertake unity issued by the government. For effective protection and maintenance of the folk custom relics, Italy is also equipped with specialized business units [5]. Government hired a large number of experts, and set up the commission, after found the need to protect cultural project, can submit an application to the government report, after complete demonstration projects will be able to enjoy the protection of the state.

\section{The foreign experience to our country in protecting intangible cultural heritage}

However, in the protection and development of intangible cultural heritage in our country at present stage, there are a lot of problems when, for example, lack of protection strength, lack of funds, serious loss of resources and so on. By studying the experience of developed countries in the protection of cultural heritage, we benefit a lot, according to the current our country present situation, we should pay special attention to the following several aspects in the development of intangible cultural heritage in the future:

\section{Attaches great importance to the construction of legislation and institutions, the standardization to protect intangible cultural heritage}

The first step to do is to and protection of intangible cultural heritage to carry on the consummation to those relevant policies and laws and regulations, in order to support our country from the aspects of system, legal protection of intangible cultural heritage of the work. All regions shall, starting from the actual situation of their own, reference "non-material cultural heritage protection law" and "cultural relics protection law" and other relevant laws and regulations, and intangible cultural heritage protection and the management method of the regulations relevant formulation, the relevant provisions of the detailed, and ensure that it can implement. Formulation development, the protection of intangible cultural heritage of the related preferential policies, involves the funds, the examination and approval of land, rental housing, fosters the talent, from multiple aspects, such as tax and innovation to build to protect intangible cultural heritage of the omni-directional service mechanism. In addition, still should pay attention to the construction of staff team and the related institutions, to ensure that can work from the organizational guarantee to protect intangible cultural heritage. In the protection of intangible cultural heritage, should pay attention to the government's leading role in the play, set up research, management of specialized agencies, configured personnel, increase financial investment, set up special funds, to ensure the protection of intangible cultural heritage work can have enough financial support. By relocation allowance, housing, and their children to school and so on preferential terms, makes the introduction of advanced talents effective mechanism, to the scientific research personnel, folk arts talent introducing, cultivating high quality talent team.

Give full play to the community and volunteers, to promote the popularization of folklore protection

People wisdom is the source of intangible cultural heritage, it only take root in people life, can 
obtain the survival soil, can maintain vitality, can inherit and spread. Based on the research of the related practice in developed countries, we find that in the protection of intangible cultural heritage, they are very importance to giving play to the role of individuals, local governments and private organizations, and some countries in order to create a universal protection atmosphere and consciousness, also details clearly defined the specific obligations, responsibilities and rights of the parties. Compared with the relatively developed foreign countries, our country civil non-material cultural heritage protection in the participation of the quantity and quality is not high, so we need to pay much attention to folk custom protection organization in the future the development of the society, for example in the community or the universities establish a folk association and so on. For the present protection of intangible cultural heritage of the existing problem of strength relatively weak, we should attach importance to the power of the volunteers; encourage volunteers to join to protect folk activities. Should make good use of the community; pay more attention to the environment of inheriting intangible cultural heritage and the cultivation of the soil. In terms of the current situation, to protect the non-material cultural heritage in particular part of the historical block protection, the traditional village work, is not only save the monomer or simple protection technology, its are linked to the life of the community, so it can't depart from the support of residents and community organizations. In Germany, for example, bamberg is one of the most famous medieval city ruins of the ancient city, it can keep till now, the key lies in the government has not moved the local people, people are still living in the house of the past, their meticulous care of the old city. So we must pay attention to the subject position of community and should be properly placed for citizens who live in historic buildings, attaches great importance to the living conditions improving, to prevent the historic building into a shell. Moreover, in order to develop public protection consciousness of culture, in order to develop the community central African material to transmit the basis of cultural heritage, we also should pay attention to in the community organization folk festivals and other related activities.

\section{Attaches great importance to the development of folk tourism landscape, realize the industrialization development of intangible cultural heritage}

Those who have great attraction for visitors, can obtain the tourism revenue country, usually has a unique intangible cultural heritage projects and folk historical buildings. The guardian, a British global travel satisfaction rankings in 2011, Japan's Tokyo judge's most popular tourist city and the country long journey, Japan was able to obtain the title of honor, largely because its realized the organic combination of traditional culture and modernization. Compared with Japan, our country has not yet been fully tapped and use their own of traditional cultural resources, that the lack of tourism cultural soft power, appeal to tourists weaker [6]. According to the statistics, through the survey of the American tourists in China, we found that $26 \%$ of the visitors are out of appreciation for places of historic interest in this, and for want to know about China's customs and way of life and the purpose of visiting tourists accounted for $50 \%$ of the total. So, each district should have the resources of intangible cultural heritage, the key to build with local trademark culture, in the development of the city culture should play the role of nurturing and nourish, shape characteristics of urban culture brand. General speaking, can from the following four aspects: first, in the building of the new town, should do well in the protection of old city, in order to can on the basis of its original features, its culture and history of landscape fully display, especially when they are at the center of the planning of villages and towns should pay attention to the characteristics of the protection of the village; Second, attaches great importance to the development of cultural activities, these cultural activities should not only reflect the spirit of The Times, at the same time should also be a folk characteristics, its main campus culture, community culture, the square culture, festival culture, etc., during these activities non-material cultural heritage of the contents shall be fully displayed, the construction of urban culture brand, and promote the development of folk custom product realization quality; Third, for intangible cultural heritage of the industry planning should be 
continuously perfect, promote the continuous sound of supporting policies, realize the healthy and fast development of the folk industry; Fourth, should be the integration of science and the local of the intangible cultural heritage resources, according to the essence, adopts the way to develop tourism. By means of the construction of folk village, festival temple fair, the activities of the folk tourism route design, the name of the place, folk architecture, folk art, and festival activities such as folk elements together, promoting the combination of tourism and intangible cultural heritage, to ensure that in a relatively short time to let visitors experience the splendor of the intangible cultural heritage.

\section{Pay attention to scientific research and field research, promote to protect intangible cultural heritage}

Although our country also carried out a lot about non-material cultural heritage of the census, but compared with other countries on the development of scientific research and the intensification of the fieldwork, do not go far enough in our country. Especially in the city today, the rapid development of economy and society, many intangible cultural heritages are gradually disappeared. So, we should do a good job in research, the records of local folk customs increase the strength and intensity of the investigation. At this stage, we need to do is, according to the construction of local social history, for the creation of folk customs, heritage motivation, development and evolution process of in-depth research, master the people of understanding and interpretation, the cognition of their own life situation, reason of folk mining [7]; Well implement investigation, writing custom annals work; By adopting the method of screening, census and together develop folk custom property inheritance directory associated with them, according to its utilization, research value, the size of the rescue the urgent degree and the representative of the strength of the factors, such as making level different list; Set up a special graphic database of non-material cultural heritage, folk books compiled and published, for the production of TV program, from the academic support the work of protection and development of intangible cultural heritage.

\section{Grab from baby education propaganda, promote the long-term education}

The convention on the protection of the intangible cultural heritage is in 2003 by the United Nations educational, scientific and cultural organization, it points out that: each contracting state shall formulate education promotion scheme for the public, especially for teens, and in order to make social respect, recognition, carry forward the intangible cultural heritage. Our country has developed a similar regulation, in the national non-material cultural heritage, his masterpiece, the interim measures of the evaluation of declaration, said: "with the help of the schools, social education and other related way, ensure that the intangible cultural heritage can happiness's, ensure it can be found in the community, especially among teenagers as cultural traditions continue to carry forward and inheriting live." For intangible cultural heritage, heritage is the main way to education, according to the present stage, many regions are not fully aware of the importance of the work. China should seriously study the experiences of developed countries, enhancement in the aspect of intangible cultural heritage of the children education consciousness [8], the school into a promotion of intangible cultural heritage, the heir to shape the intangible cultural heritage in pairs to cultivate the main venues. In the present stage our country middle and primary school Chinese textbook used by, lack of non-material cultural heritage. So, we should be those things related to intangible cultural heritage to join the school textbooks, strive to build non-material cultural heritage education mechanism, organize regular non-material cultural heritage of the lecture, training classes for campus activities, folk and folk art performances, etc., only in this way can make the intangible cultural heritage into their childhood life and the important content of memory, to make them produce kindness of intangible cultural heritage, let them in the future life consciously engage in the activity of non-material cultural heritage of the inheritance. 


\section{Reference}

[1] Wen-yan liuto. Protect cultural heritage Guardian spirit home [J]. Journal of Liaoning today, 2006 (3): 21-22.

[2] Skill, Ceng Xi. Intangible cultural heritage inheritance difficult [J]. Journal of outlook, 2008 (5): $11-12$.

[3] YuanLi, gu jun from. Industrialization development of intangible cultural heritage and the commercialized management [J], Henan social science, 2009 (04): 20-21.

[4] Tian Xiao. Focus on intangible cultural heritage [J]. Journal of outlook, 2005 (33): 33-34.

[5] YuDan. How to keep Guizhou cultural memory [J]. Contemporary Guizhou, 2006 (14): 44-45.

[6] Chen. Surprise: "Chengdu model" flowery appearance [J]. Journal of party construction in Sichuan province (city), 2007 (6): 26-27.Dodson TB. 